\title{
Prevalence Of Obesity Among Children Studying In Government And Private Schools In District Anantnag Age Group (6-12 Years)
}

\author{
Dr. Naheed Vaida \\ Senior Associate Professor, Institute of Home Science, University of Kashmir \\ Hazratbal, Srinagar, 190006
}

\begin{abstract}
The present study was conducted to compare the prevalence of obesity among children studying in government and private schools in the age group of 6-12 years in District Anantnag. An equal number of sample was taken from both government as well as private schools. A total number of hundred subjects were chosen randomly and all of them belonged to rural area. The data was obtained through self designed questionnaire. The main causes of obesity found among school children were decreased physical activity, increased levels of calorie intake and sedentary life style. Mostly the children from high socio-economic group were found to be more obese because of their sedentary life style and increased food intake levels. Owing to this increasing trend of obesity in school children it is necessary to take an early step towards this issue so that it may not become health hazard for the future generation. The problem of growing obesity should be solved as soon as possible by the coordinated efforts of both children and their parents. Children should follow an active life style and eat in right amounts to keep themselves healthy and free from the threat of obesity.
\end{abstract}

Key Words: Obesity, Prevalence, Physical activity, Children

\section{Introduction}

Obesity is a medical condition in which excess body fat is accumulated in the body to the extent that it may have an adverse effect on health, leading to reduced life expectancy and increased health problems. Obesity has reached epidemic proportions globally. More than one billion adults are overweight and at least 300 million of them are clinically obese. Significantly obesity is increasing rapidly in developing countries undergoing rapid nutrition and lifestyle transition and it often exists with under nutrition. The rising prevalence of obesity in developing countries is largely due to rapid urbanization and mechanization which has led to reduction in the energy expenditure along with an increase in energy intake due to increasing purchasing power and availability of high fat and energy dense fast foods. Obesity is a leading preventable cause of death worldwide and authorities view it as one of the most serious public health problems of $21^{\text {st }}$ century. Obesity increases the likelihood of various diseases particularly type 2 diabetes, breathing difficulties during sleep, certain types of cancer and osteoarthritis. Childhood obesity is a condition where excess body fat negatively affects a child's health or well being. As methods to determine body fat directly are difficult, the diagnosis of obesity is often based on B.M.I. The term overweight rather than obese is often used in children as it is less stigmatizing. Childhood obesity may not be a wide spread phenomenon as yet but the rapidly increasing numbers do provide us cause to be concerned about it. Researches show that kids have lesser obesity associated health problems in comparison to adults. However, there is a high possibility of their growing up into overweight individuals which accentuates the risk of their falling prey to acute illness like heart diseases, diabetes and so on at later stages in life. One may ask what reasons lie behind children turning overweight or obese? The truth is that this condition could be fall out of any one or combination of a number of reasons. The very common ones accounting for childhood obesity are genetic factors, inadequate or total absence of physical activities like exercise, unhealthy eating habits and so on. In few cases, obesity in kids could be a consequence of a medical condition. The problem of obesity in childhood can also be associated with certain family habits like their eating and activity patterns. Genetic factors can hike up the possibility of a child getting overweight. Two factors that play a vital role in deciding a kid's weight is his/her eating or activity patterns. Due to the popularity of the video games and television, many children nowadays in the urban regions spend a lot of time remaining inactive.Changes in environmental and societal factors are likely the main explanation for doubling of severe childhood obesity over the last thirty years. Obesity is encouraged by such obesogenic environmental conditions that promote overeating and inactivity is either already present or emerging in most populations. 


\section{Scope and Objectives}

Childhood obesity is a public health problem of increased concern in developed world and in populations undergoing cultural transition. Keeping the increasing trend of obesity in mind the present study has been undertaken. This study focuses on the comparison of obesity among children studying in government and private schools in district Anantnag of $J \& K$. The main objectives of this study are:

- To screen the study sample for the prevalence of obesity by using anthropometric measurements and comparing them with given standards by WHO.

- To assess and calculate nutrient intake of the study sample using $24 \mathrm{hr}$ dietary recall and comparing them with RDA'S given by ICMR.

- To find out the factors contributing to childhood obesity among the study sample.

- To estimate difference in prevalence of obesity in both govt. and private school children with respect to their socio economic standards.

\section{Review of Literature}

Ramachandran et. al. (2002) studied children from six schools, two each from high, middle and lower income group in Chennai. The prevalence of overweight including obese adolescents ranged from $22 \%$ in better of schools to $4.5 \%$ in lower income group. In a Delhi based school with tuition fees more than 2500 per month, the prevalence of overweight was $31 \%$ of which $7.5 \%$ were frankly obese. In a study by Eberstadt (2003) dramatic increase in the number of people who were overweight or obese has also been reported in Canada, Australia and many European countries. Ogden et. al. (2002) in the Journal of American Medical Association reported that $15 \%$ of 6 to 9 year olds in the U.S. are overweight and the rates of childhood obesity have been steadily increasing since 1970's.Anderson et. al. (2002), found that children who are unsupervised when they come home from school may eat less nutritious snacks and spend more time watching television or playing computer games. Steven (1996) found a strong relationship between the prevalence of overweight and hours of television viewed. They concluded that reduction in viewing time could prevent this increasing chronic health condition. A study conducted by Strauss (2000) found a significant relationship between obesity and lowered self esteem in early adolescence. Young obese adolescents and white females had the lower levels of self esteem followed by obese Hispanic females. In a study by Moran (1999), children express negative attitude towards their obese peers as early as in kindergarten and there is a clear association between obesity and low self-esteem especially in adolescents. A study by Zaklad (2006) showed that simple obesity in children aged 3-15 years is connected with familial and environmental factors, including incorrect eating habits. Dietary treatment consisting in the lowering of energetic value of the diet through the reduction of fat consumption and quantity and quality changes with respect to carbohydrates consumption decreased the children's obesity, and was more effective in the older age group (7-15 yrs). Dietary treatment normalizes the lipid profile in children. Significant body mass loss has been observed in children in whose diet the amount of proteins and their share in the total energy value only slightly differs from the level before the dietary treatment. The amount of proteins in the children's diet was within the range of physiological recommendations

\section{Materials And Methods}

The present study was undertaken to assess obesity among children studying in government and private schools in district Anantnag.

The data was collected from two sources:

i) Primary source

ii) Secondary source.

Primary source consists of questionnaire cum interview schedule which was used for collecting information from the selected sample. Secondary source comprised of information obtained from books, published and unpublished dissertations, journals and the latest information from internet. A sample of 100 children, 50 from government and 50 from private schools in the age group of 6 to 12 years were selected from four schools (two government and two private institutions). In each school boys and girls were randomly selected. The main tool used for collection of data was questionnaire cum interview schedule. The questionnaire was framed in simple language so that the respondents could answer them easily. The questionnaire was divided into following sections:

\section{Section A}

General Information

Section B

Anthropometric measurements 
A. Height: Height of the sample was recorded thrice for accurate measurements. Height was recorded in centimetres to the nearest of $0.1 \mathrm{~cm}$ with a standard tape. The subjects were asked to stand straight without shoes against the wall of the room.

B. Weight: Weight of the sample was recorded in kilograms with the help of a weighing machine. The subjects were weighed with minimum clothing and without shoes, standing upright with arms hanging on sides.

C. Body Mass Index: The body mass index of the sample was calculated on the basis of the height and weight using the formula.

BMI = Weight $(\mathrm{kg}) /$ Height $\left(\mathrm{m}^{2}\right)$

Since the height of the patients was recorded in centimetres, for the calculation of BMI height in centimetres was first converted into meters.

\section{Section C}

Clinical Assessment: This section revealed information regarding the health status of the subjects. It also includes the clinical examination of the respondents to check for obesity signs and symptoms.

\section{Section D}

24-Hour Recall Method: In this section information about the dietary habits of the sample was included. This section revealed information regarding the nutrient intake. A $24 \mathrm{hr}$ recall method was used to obtain information regarding the intake of calories, proteins and fats. The daily intake of nutrients were calculated and compared to the RDA given by I.C.M.R.

\section{Section E}

Personal Information: This section revealed information about the eating habits of the subjects. In addition to this it extracted the information regarding the type of work done, the family size, income and the kind of life they are living.

Analysis of Data

The data obtained through questionnaire was consolidated, analysed and interpreted as per the requirements of objectives using specific statistical tools e.g., mean and standard deviation.

\section{Results and Discussion}

Table 1: Distribution of sample according to BMI.

\begin{tabular}{|l|l|l|l|l|l|}
\hline \multicolumn{1}{|c|}{ BMI (kg/m $\left.\mathbf{m}^{2}\right)$} & \multicolumn{1}{c|}{ Group } & \multicolumn{2}{c|}{ Govt. School } & \multicolumn{2}{c|}{ Private school } \\
\hline & & Total subjects & $\%$ age & $\begin{array}{l}\text { Total } \\
\text { subjects }\end{array}$ & $\%$ age \\
\hline$<15$ & Starvation & 2 & $4 \%$ & 0 & $0 \%$ \\
\hline $15-18.5$ & $\begin{array}{l}\text { Under } \\
\text { nourished }\end{array}$ & 28 & $56 \%$ & 17 & $34 \%$ \\
\hline $18.5-23$ & Normal & 18 & $36 \%$ & 23 & $46 \%$ \\
\hline $23-25$ & Over weight & 2 & $4 \%$ & 7 & $14 \%$ \\
\hline$>25$ & Obese & 0 & $0 \%$ & 3 & $6 \%$ \\
\hline Total & & 50 & & 50 & \\
\hline
\end{tabular}

Table 1 depicts that in government schools, $4 \%$ children were overweight. In private schools $14 \%$ of the subjects were overweight and $6 \%$ were obese. The grouping has been done as per WHO, IOTF criteria based BMI.

Table 2: Distribution of sample according to fat percentage.

\begin{tabular}{|l|l|l|l|l|l|l|l|}
\hline \multicolumn{3}{|c|}{ Male Group } & \multicolumn{4}{c|}{ Female Group } \\
\hline $\begin{array}{l}\text { Fat \%age } \\
\text { values }\end{array}$ & Group & $\begin{array}{l}\text { Govt. } \\
\text { School } \\
\% \text { age }\end{array}$ & $\begin{array}{l}\text { Private school } \\
\% \text { age }\end{array}$ & $\begin{array}{l}\text { Fat \%age } \\
\text { values }\end{array}$ & $\begin{array}{l}\text { Group } \\
\text { School } \\
\% \text { age }\end{array}$ & $\begin{array}{l}\text { Private } \\
\text { school } \\
\% \text { age }\end{array}$ \\
\hline$<10 \%$ & $\begin{array}{l}\text { Under } \\
\text { nourished }\end{array}$ & $0=0 \%$ & $0=0 \%$ & $<15 \%$ & $\begin{array}{l}\text { Under } \\
\text { nourished }\end{array}$ & $0=0 \%$ & $0=0 \%$ \\
\hline $10-20 \%$ & Normal & $15=60 \%$ & $11=45.8 \%$ & $15-25 \%$ & Normal & $21=84 \%$ & $15=57.7 \%$ \\
\hline $20-25 \%$ & Overweight & $10=40 \%$ & $9=37.5 \%$ & $25-30 \%$ & Overweight & $4=16 \%$ & $6=23.1 \%$ \\
\hline$>25 \%$ & Obese & $0=0 \%$ & $4=16.6 \%$ & $>30 \%$ & Obese & $0=0 \%$ & $5=19.2 \%$ \\
\hline
\end{tabular}


In table 2, government and private school children are arranged according to body fat guidelines from American Dietetic Association based on body fat values. It was found that in government schools $60 \%$ male subjects were normal and $40 \%$ were overweight and in females $84 \%$ subjects were normal and $16 \%$ were overweight. In case of private schools $46 \%$ male subjects were normal, $37 \%$ were overweight and $17 \%$ were obese. In female category $58 \%$ subjects were normal, $23 \%$ subjects were overweight and $19 \%$ subjects were obese. By considering the results of both BMI and body fat percentage values it was found that obesity was higher in private schools as compared to government school children. It was also found that maximum percentage of obesity was among the female subjects as compared to their male counterparts. In the government schools, the most common signs of malnutrition found among the subjects were pale eyes (46\%) bleeding gums and brittle nails $28 \%$ each, easily pluckable hair (24\%) and pale skin (22\%). Other signs of malnutrition found among government schools children were spoon shaped nails (18\%), dry skin (18\%), grey hair (10\%), thick tongue and swollen gums $8 \%$ each, dry hair and red tongue $4 \%$ each. Similarly in private schools the most common signs of malnutrition were pale eyes $(40 \%)$, brittle nails $(24 \%)$, easily pluckable hair and bleeding gums $(22 \%)$ each, pale skin and thick tongue $16 \%$ each and dry skin $18 \%$. The other signs of malnutrition found among private school children were spoon shaped nails (14\%), dry hair and red tongue $8 \%$ each, swollen gums $(6 \%)$ and grey hair.

Table 3: Distribution of sample based on clinical examination.

\begin{tabular}{|c|c|c|c|c|}
\hline \multirow{2}{*}{$\begin{array}{ll}\text { Signs } & \text { and } \\
\text { symptoms } & \end{array}$} & \multicolumn{2}{|c|}{ Govt. Schools } & \multicolumn{2}{|c|}{ Private schools } \\
\hline & Number & Percentage & Number & Percentage \\
\hline Pale eyes & 23 & 46 & 20 & 40 \\
\hline Pale skin & 11 & 22 & 8 & 16 \\
\hline Dry skin & 9 & 18 & 9 & 18 \\
\hline Thick tongue & 4 & 8 & 8 & 16 \\
\hline Red tongue & 2 & 4 & 4 & 8 \\
\hline $\begin{array}{l}\text { Easily pluckable } \\
\text { hair }\end{array}$ & 12 & 24 & 11 & 22 \\
\hline Dry hair & 2 & 4 & 4 & 8 \\
\hline Grey hair & 5 & 10 & 2 & 4 \\
\hline Bleeding gums & 14 & 28 & 11 & 22 \\
\hline Swollen gums & 4 & 8 & 3 & 6 \\
\hline Brittle nails & 14 & 28 & 12 & 24 \\
\hline Spoon shaped nails & 9 & 18 & 7 & 14 \\
\hline
\end{tabular}

The study was further carried to find out about the personal life of the subjects, their way of life, their socio economic status, eating habits, activity pattern etc. It was found that the parents of government school children were less educated. Their literacy rate was very low while as the parents of children studying private schools were having a high literacy rate. Most of the children were living in joint families. In government schools the percentage of children living in joint families was $56 \%$ and $44 \%$ children were living in nuclear families while as in private schools $54 \%$ children were living in joint families and $46 \%$ in nuclear families. In government schools, children were not getting much of pocket money while as in private schools, children were given a sufficient amount of pocket money by parents. From the study it was found that in government schools, $18 \%$ of children were given Rs. 5 per day, $58 \%$ were given Rs. $10,10 \%$ got Rs. $15,6 \%$ were given Rs.20 and $8 \%$ children were not given any pocket money. In private schools $44 \%$ children were given Rs. $10,8 \%$ were given

Rs.15, 32\% were given Rs.20, 4\% were given Rs.50 and $12 \%$ were given Rs.30 as their daily pocket money. The amount of pocket money got by each student is directly related to the additional intake apart from their usual diet. As the govt. school children were getting less amount of pocket money as compared to private school children, they were not eating a variety of eatables which could have increased their calorie intake. It was further observed that in govt. schools $24 \%$ children spend their pocket money only on chips, $12 \%$ on sweets, $8 \%$ on chocolates, $12 \%$ on fruits and $36 \%$ children spend money on all of the above eatables while as $8 \%$ children do not get any pocket money to spend. Similarly in private schools $22 \%$ of children spend their pocket money on chips, $8 \%$ on sweets, $16 \%$ on fruits, $4 \%$ on chocolates and a maximum number of children i.e., $50 \%$ spend their money by eating all the above items. 
Figure 1: MODE OF TRASPORTATION

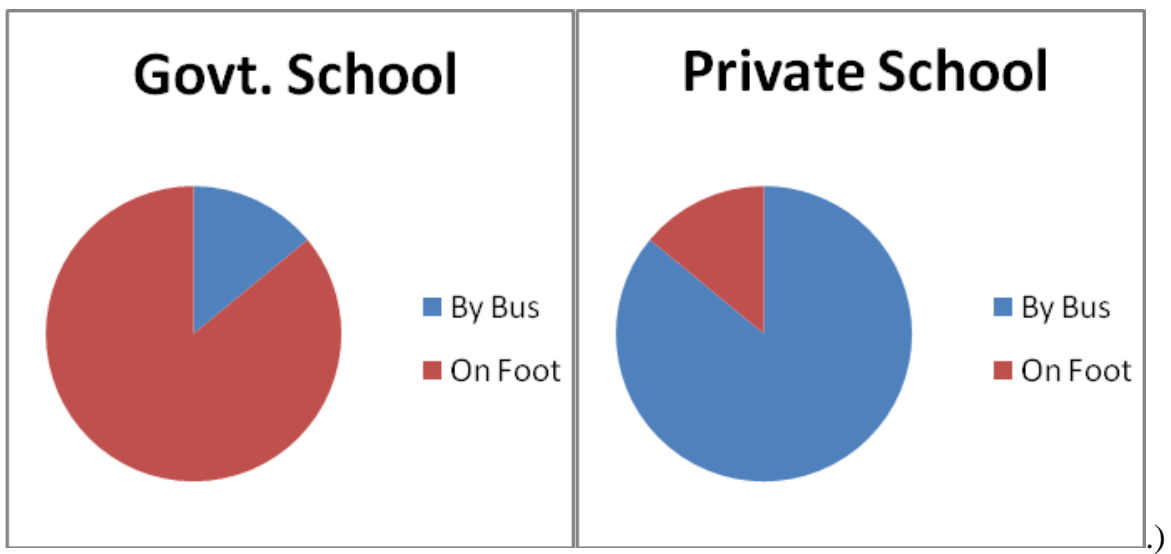

Figure 1 gives us a clear idea about the ways and means by which the children reach their schools. Those children who go to school on foot have to spend a lot of energy in walking, while as those children who go to school by bus need less energy to reach their destination. From the study we found that in govt schools $86 \%$ children go to school on foot and only $14 \%$ children go by bus, while as in private schools $86 \%$ children go to school by bus and only $14 \%$ reach the school on foot.

Figure 2: TIME SPENT ON VIEWING TV
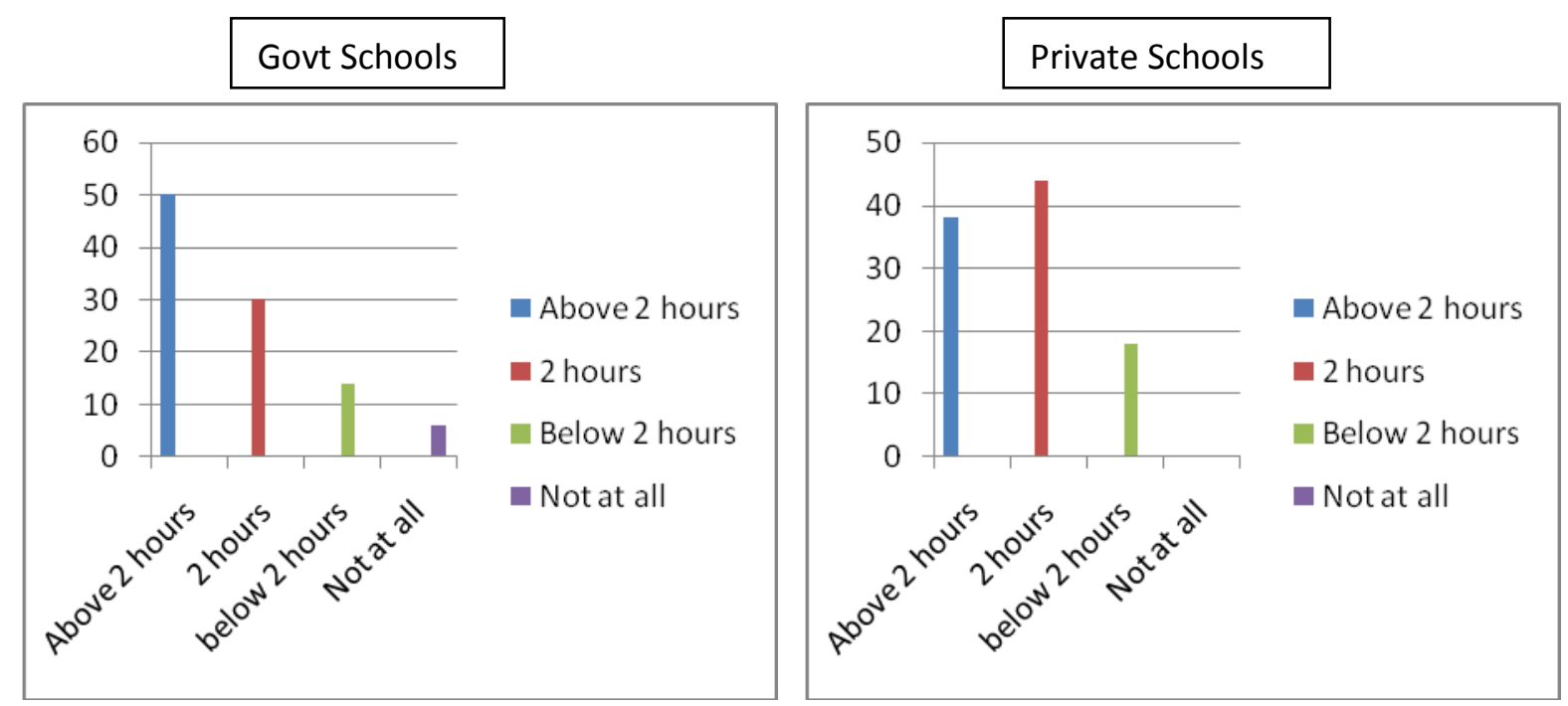

Figure 2 reveals information about the time spent by school children in watching TV per day. It was found that in govt. schools $50 \%$ children watch TV for more than 2 hours, $30 \%$ for 2 hours, $14 \%$ below 2 hour and $6 \%$ children did not watch TV at all. In private schools $44 \%$ children used to watch TV for 2 hours and $38 \%$ children watch for more than 2 hours and $18 \%$ for less than 2 hours per day.

It was further seen that private school children study for maximum time during the day as compared to govt school children. The study further revealed that $38 \%$ of govt. school children study for 2 hours, $60 \%$ for 1 hour and only $2 \%$ children study for 3 hours. In private schools $48 \%$ children study for 2 hours, $28 \%$ for 3 hours and $24 \%$ children study for only 1 hour 


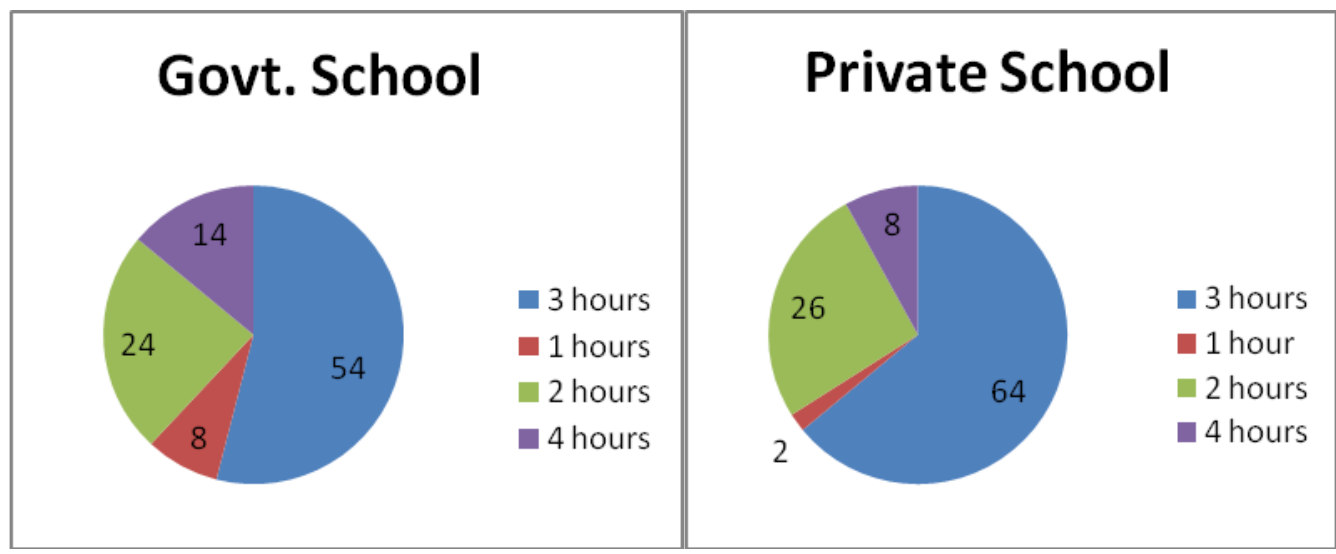

Figure 3 reveals that govt. school children spend more time on playing as compared to private school children. It was found that in govt. schools 54\% children play for 3 hours, $24 \%$ for 2 hours, $8 \%$ for 1 hour and $14 \%$ for 4 hours. In private schools $64 \%$ children play for 3 hours, $26 \%$ for $2,8 \%$ for 4 and $2 \%$ for 1 hour.

Table 4: Distribution of sample according to intake of energy.

\begin{tabular}{|l|l|l|l|l|l|l|l|l|}
\hline \multirow{2}{*}{$\begin{array}{l}\text { Age } \\
\text { group(in } \\
\text { years) }\end{array}$} & \multicolumn{9}{|c|}{ Energy(Kilo calories) } \\
\cline { 2 - 10 } & $\begin{array}{l}\text { Gax } \\
\text { value }\end{array}$ & $\begin{array}{l}\text { Min } \\
\text { value }\end{array}$ & Mean & SD & $\begin{array}{l}\text { Max } \\
\text { value }\end{array}$ & $\begin{array}{l}\text { Min } \\
\text { value }\end{array}$ & Mean & SD \\
\hline $5-7$ & 1951 & 1198.7 & 1640.8 & 197.6 & 1940 & 1678 & 1803.7 & 91.5 \\
\hline $8-10$ & 1641.7 & 1973 & 1087.4 & 55 & 2165 & 1695 & 1880.4 & 76.3 \\
\hline $11-13$ & 1735 & 1950 & 1842.5 & 56 & 2097 & 1937 & 2004.8 & 53.6 \\
\hline
\end{tabular}

In private school children in the age group of 5-7 years, it was found that the maximum energy intake was $1940 \mathrm{kcal}$ and the minimum intake was $1678 \mathrm{kcal}$. The mean energy intake was $1803.7 \mathrm{kcal}$ with a standard deviation of 91.5 as against 1640.8 in government school children. Similarly in the age group of 8-10 years the maximum energy intake value for private school children was $2165 \mathrm{kcal}$ and the minimum value was $1695 \mathrm{kcal}$

The mean energy intake was 1880.4 with a standard deviation of 76.3 , while as in government school children

the mean energy intake was 1087.4 In the age group of 11-13 years the maximum energy intake value for private school children was $2097 \mathrm{kcal}$ and the minimum intake was $1937 \mathrm{kcal}$. The mean energy intake was 2004.8 with a standard deviation of 53.6 as against mean energy intake of 1842.5 in case of government school children.

Table 5: Distribution of sample according to protein intake levels.

\begin{tabular}{|l|l|l|l|l|l|l|l|l|}
\hline \multirow{2}{*}{$\begin{array}{l}\text { Age } \\
\text { group }\end{array}$} & \multicolumn{9}{|c|}{ Protein(grams) } \\
\cline { 2 - 10 } & \multicolumn{9}{|c|}{ Government schools } & $\begin{array}{l}\text { Private schools } \\
\text { Max } \\
\text { value }\end{array}$ & $\begin{array}{l}\text { Min } \\
\text { value }\end{array}$ & Mean & SD & $\begin{array}{l}\text { Max } \\
\text { value }\end{array}$ & $\begin{array}{l}\text { Mean } \\
\text { value }\end{array}$ & SD \\
\hline $5-7$ & 41.2 & 26 & 35 & 4.7 & 42 & 34 & 37.7 & 1.97 \\
\hline $8-10$ & 55 & 37 & 42 & 5.8 & 56.3 & 32 & 42.2 & 5.9 \\
\hline $11-13$ & 56 & 39.5 & 48.7 & 5.8 & 57.4 & 48 & 54.8 & 2.8 \\
\hline
\end{tabular}

The maximum protein intake among children studying in government schools in the age group of 5-7 years was 41.2 and minimum value was 26 grams whereas, in private school maximum amount of protein intake was 42 gms and the minimum intake was $34 \mathrm{gms}$. The mean protein intake was 37.3 with a standard deviation of 1.97. In the age group of 8-10 years, mean value found was 42 as compared to children studying in private schools where mean value found was 42.2. The maximum protein intake in the age group of 11-13 was 56 gms and 57.4 gms respectively among government and private school children and the minimum intake was almost 48 gms.

The mean protein intake was 54.8 with a standard deviation of 2.8 . 
Prevalence Of Obesity Among Children Studying...

Table 6: Distribution of sample according to fat intake levels.

\begin{tabular}{|l|l|l|l|l|l|l|l|l|}
\hline \multirow{2}{*}{$\begin{array}{l}\text { Age } \\
\text { group }\end{array}$} & \multicolumn{9}{|c|}{ Gat(grams) } \\
\cline { 2 - 10 } & \begin{tabular}{l} 
Government schools \\
\cline { 2 - 10 } \\
value
\end{tabular} & $\begin{array}{l}\text { Min } \\
\text { value }\end{array}$ & Mean & SD & $\begin{array}{l}\text { Max } \\
\text { value }\end{array}$ & $\begin{array}{l}\text { Min } \\
\text { value }\end{array}$ & Mean & SD \\
\hline $5-7$ & 41.7 & 31 & 34.8 & 2.8 & 43.5 & 33.3 & 36.2 & 3.4 \\
\hline $8-10$ & 43 & 32 & 33 & 3.5 & 38 & 33.1 & 35.7 & 2.6 \\
\hline $11-13$ & 40.9 & 33 & 37.9 & 2.9 & 45.1 & 32 & 37.5 & 3.7 \\
\hline
\end{tabular}

As far as fat intake was concerned maximum amount consumed in the age group 5-7 years was 41.7 grams by students studying in government schools as compared to 43.5 grams by students studying in private schools. Standard deviation found was 2.8 and 3.4 respectively. In the age group of 8 to 10 years, maximum value for fat intake in government schools was 43 grams whereas minimum value was 32 grams and among private school students maximum intake was 38 grams and minimum 33.1. The maximum fat intake was 40.9 and minimum 33 grams in government schools and maximum of 45.1 gms and the minimum 32 gms in private schools among the age group of 11-13. The mean intake of fat was 37.5 with a standard deviation of 3.7.

\section{Discussion}

In the present study it was observed that there has been a significant increase in overweight and obesity in children belonging to private schools as compared to govt. school children. In private school children the prevalence of overweight and obesity was $14 \%$ and $6 \%$ respectively while as in govt. schools the prevalence of overweight and obesity was $4 \%$ and $0 \%$ respectively based on BMI values and on the basis of body fat percentage values. $23 \%$ private school children were overweight and $19 \%$ were obese while as in govt. schools $16 \%$ children were overweight. In a study conducted by Ramachandran et. al. (2002), the prevalence of overweight including obese adolescents ranged from $22 \%$ in better off schools to $4.5 \%$ in lower income group which is to some extent similar with the present study. In our study it was also seen that major cause of obesity in school children was because of high socioeconomic status of the people, changing lifestyle and economic improvement. In a study conducted Ramachandran et. al. (2002) in a Delhi based school with tuition fees more than 2500 per month, the prevalence of overweight was $31 \%$ of which $7.5 \%$ were frankly obese. In a study by Eberstadt (2003), dramatic increases in the number of people are overweight or obese has also been reported in Canada, Australia and many European countries. Lack of physical activity was another culprit in our study which resulted in high rates of overweight and obesity. Sedentary activities like TV watching, playing video games etc. were the main causes of obesity in this category. A study from nutrition researches at UNC Chapel Hill asserts that lack of physical activity and not increased caloric intake is responsible for the growing rate of obesity among youth aged 12-19 years. According to Centres for Disease Control (CDC) several environment factors have contributed to rising rates of obesity among youth, including more hours spent in sedentary activities such as watching TV and playing computer or video games and the availability of fast foods that lead to diets high in fat and sugar. In a study by Anderson et. al. (2002), it was found that children who are unsupervised when they come home from school may eat less nutritious snacks and spend more time watching television or playing computer games. All the studies are in accordance with our present study which clearly shows decreased physical activity as one of the causes of obesity in children. Therefore, it is necessary to increase the physical activity levels of children to decrease the growing rates of obesity which was also depicted in a study by Tanson (2003). Unless we get our children moving, we will be unable to make any significant progress in terms of weight management.

\section{Summary and Conclusion}

The results revealed that maximum percentage of overweight $(14 \%)$ and obesity $(6 \%)$ was found in private school children as compared to govt. school children overweight. It was also found that the maximum percentage of malnourished children were from govt. schools as compared to private schools.

Maximum time of private school children was spend on sedentary activities like TV watching, studying and sitting idle without doing any household jobs. In comparison to this govt. school children were spending less time on sedentary activities. They were spending a lot of time in playing and doing household jobs. 


\section{Conclusion}

It was concluded from the study that the obesity was prevalent in the school children and the prevalence was more in private schools as compared to government schools. The main causes of obesity found among school children were decreased physical activity, increased levels of calorie intake and sedentary life style. Mostly the children from high socio-economic group were found to be more obese because of their sedentary life style and increased intake levels. Owing to this increasing trend of obesity in school children it is necessary to take an early step toward this issue so that it may not become any health hazard for the future generation. The problem of growing obesity should be solved as soon as possible by the coordinated efforts of both children and their parents. Children should follow an active life style and eat in right amounts to keep themselves healthy and free from the threat of obesity. Physical exercise is the main treatment for obesity. Moreover, it is important to improve diet quality by reducing the consumption of energy dense foods such as those high in fat sugars and by increasing the intake of dietary fibre. To supplement this or in case of failure anti obesity drugs may be taken to reduce appetite or inhibit fat absorption

\section{Suggestions}

To overcome the growing burden of obesity in school children following suggestions should be kept in mind:

- Physical activity levels should be increased.

- The diet should be rich in fibre.

- Pocket money given to the children should be minimized.

- The diet should be rich in fruits and vegetables which are good sources of vitamins and minerals.

- Intake of fatty foods should be minimized as much as possible.

- Foods such as calorie rich drinks and snacks and other junk foods should be avoided.

- Stress should be reduced as it can influence a child's eating habit. Feeling of depression can cause a child to over eat.

- Activities like tracking, biking or swimming should be encouraged to adopt healthy living habits.

- TV watching should be minimized as much as possible because it encourages lack of physical activity.

- Dietician should be consulted from time to time for advice on proper diet.

\section{Bibliography}

[1]. Anderson P \& Butcher KLP (2002), "Maternal Employment and overweight children: Nationals Bureau of Economic Research".

[2]. Eberstadt M (2003), "The Child Fat Problem", Policy Review, 117, Hoover Institute, Stanford University Review.org/FEB03/Eberstadt.htm.

[3]. Moran R (1999), "Evaluation and Treatment of Childhood Obesity", American Family Physician, American Academy of Family Physicians. http://www.aafp/990215ap/861.html.

[4]. Ogden C, Flegal K, Carroll M and Johnson C (2002), "Prevalence and Trends in Overweight among US children and adolescents, 1999-2000. Journal of American Medical Association, 288(14), 1728-1732.

[5]. Ramachandran A, Snehalatha C, Vinitha R, Thayyil M, Satish Kumar CK, Sheebal et. al.,(2002), "Prevalence of overweight in Urban Indian adolescent school children. Diabetes Res Clin Pract, 57:185190.

[6]. Strauss R (2000), “Childhood Obesity and Self-Esteem, Paediatrics, 105(1).

[7]. Steven L, Gortmarker, Aviva M ,Arthur M, Sobul AM, Karen P, Graham A, Colditz, William HD.( 1996), 'Television Viewing as a cause of increasing obesity among children in United States 19861990.Arch PediatrAdolesc Med, 150(4) 356-362

[8]. Tanson W (April 14, 2003), "Adolescent obesity largely caused by lack of physical activity, study finds. News service, UNC school of public health. http://www.unc.edu/news.serv/research/apr03/sutherland040903.html.

[9]. Zaklad Z, Instylul M, Dziecka ul.K, Warszawa. (2006), 'Simple obesity in children -A study on the role of nutritional factors.' Med WiekvRozwol, Jan-March 10(1) 3-191. 